\title{
Competition or cooperation? - the concurrent development of grain weevil (Sitophilus granarius L.) and lesser grain borer (Rhyzopertha dominica F.) on barley grain
}

\author{
Rywalizacja czy kooperacja? - wspólny rozwój wołka zbożowego \\ (Sitophilus granarius L.) i kapturnika zbożowca (Rhyzopertha dominica F.) \\ na ziarnie jęczmienia
}

\author{
Mariusz Nietupski*
}

\section{Summary}

This study consists of an evaluation of the development of two primary grain pests: lesser grain borer (Rhyzopertha dominica F.) and grain weevil (Sitophilus granarius L.) on barley grain. The research objective was to evaluate the concurrent development of these two species and to determine if there was a competition between them, and if so which species was winning it. Parameters of the populations of these pests were examined (abundance of the offspring generation, amount of dust and loss of grain mass) in variants where the pest species had identical conditions for development or when one had an advantage (in terms of their number or duration of being settled on the grain). The species developed under constant thermal and humidity conditions maintained in a climate chamber, for 8 weeks. When they develop independently, there was a linear relationship between the growth in the number of offspring and the dust mass and kernel mass loss. When developing together with the other species, the lesser grain borer had better conditions for the development, probably owing to greater availability of dust used by young larvae of $R$. dominica. The lesser grain borer formed larger progeny populations and had a more dynamic development as a species than the grain weevil did.

Key words: grain weevil, lesser grain borer, concurrent development of storage pests, barley grain

\section{Streszczenie}

Badania dotyczyły oceny rozwoju dwóch pierwotnych szkodników ziarna zbóż: kapturnika zbożowca (Rhyzopertha dominica F.) i wołka zbożowego (Sitophilus granarius L.) na ziarnie jęczmienia. Celem badań była próba oceny wspólnego rozwoju tych gatunków oraz określenie czy istnieje między nimi konkurencja oraz który gatunek ewentualnie ją wygrywa. Badano parametry populacji szkodników w kombinacjach (liczebność pokolenia potomnego, masę pyłu oraz ubytek masy ziarna), gdy szkodniki miały identyczne warunki do rozwoju lub jeden z nich miał przewagę (liczebnościową lub czas zasiedlenia). Gatunki rozwijały się w stałych warunkach termiczno-wilgotnościowych w komorze klimatyzacyjnej przez okres 8 tygodni. W przypadku samodzielnego rozwoju szkodników stwierdzono liniową zależność między wzrostem liczebności populacji potomnej a masą pyłu i ubytkiem masy ziarniaków. Wspólny rozwój obu gatunków stwarzał lepsze warunki do rozwoju kapturnikowi zbożowemu, prawdopodobnie dzięki większej dostępności pyłu wykorzystywanego przez młode larwy $R$. dominica. Kapturnik zbożowiec tworzył liczniejsze populacje potomne i był gatunkiem o bardziej dynamicznym rozwoju w porównaniu z wołkiem zbożowym.

Słowa kluczowe: wołek zbożowy, kapturnik zbożowiec, wspólny rozwój szkodników magazynowych, ziarno jęczmienia

\footnotetext{
Uniwersytet Warmińsko-Mazurski w Olsztynie Katedra Entomologii, Fitopatologii i Diagnostyki Molekularnej Prawocheńskiego 17, 10-722 Olsztyn

*corresponding author: mariusz.nietupski@uwm.edu.pl ORCID: 0000-0001-6509-4579
} 


\section{Wstęp / Introduction}

Żerowanie szkodników magazynowych na ziarnie zbóż, produktach ich przemiału, paszach i szeroko pojętej żywności jest globalnym problemem, który wiąże się z wymiernymi stratami. Wynikają one przede wszystkim z faktu ubytku masy produktów, na których żeruje szkodnik (Hagstrum i Subramanyam 2006), pojawu zanieczyszczeń oraz ogólnego spadku ich jakości i wartości (Stejskal i wsp. 2014). Pojawiające się w magazynach szkodniki, (typ Arthropoda), zaliczane są do czterech rzędów: chrząszczy (Coleoptera), motyli (Lepidoptera), roztoczy (Acari) i gryzków (Psocoptera) (Stejskal i wsp. 2003). Dzieli się je również na grupę szkodników pierwotnych (uszkadzających całe ziarno zbóż) i wtórnych, które tej zdolności nie posiadają (Aulicky i wsp. 2016). Różne gatunki szkodników rzadko kiedy w warunkach magazynów i przechowalni mają możliwość samodzielnego żerowania na produktach zbożowych. Bardzo często żerują wspólnie, tworząc zgrupowania kilku gatunków. Gatunki będące szkodnikami pierwotnymi [m.in. Sitophilus granarius (L.), Sitophilus oryzae (L.), Rhyzopertha dominica (F.), Trogoderma granarium Ev., Ephestia küehniella Zell. i Plodia interpunctella (Hübn.)] ułatwiają późniejszy rozwój szkodnikom wtórnym [roztocze, Oryzaephilus surinamensis (L.), Tribolium spp. i inne] (Hagstrum 2000; Aulicky i wsp. 2016). Wspólne zasiedlanie produktów zbożowych przez szkodniki zależy od wielu czynników, związanych $\mathrm{z}$ warunkami wilgotnościowo-termicznymi panującymi w sezonie oraz długością okresu składowania i sposobem magazynowania ziarna zbóż (Vela-Coiffier i wsp. 1997; Hagstrum 2000). Duże znaczenie ma również skład gatunkowy i liczebność szkodników obecnych w magazynach lub silosach typu bin we wcześniejszych latach (Hagstrum 1987). W czasie tego procesu dochodzi do częstej zmiany gatunków dominujących $\mathrm{w}$ przechowywanym ziarnie, jednak w początkowej fazie zasiedlania ziarna ważną rolę pełni obecność gatunków będących szkodnikami pierwotnymi. Jednymi $\mathrm{z}$ najgroźniejszych szkodników pierwotnych w Polsce i na świecie są wołek zbożowy (S. granarius) i kapturnik zbożowiec ( $R$. dominica) (Jia i wsp. 2008; Klejdysz i Nawrot 2010; Edde 2012; Nietupski i wsp. 2017). Pomiędzy tymi gatunkami istnieje różnica w sposobie zasiedlania ziarna, która dotyczy owipozycji i pobierania pokarmu przez larwy. Samice wołka zbożowego wygryzają niewielki otwór w ziarniaku, do którego składają jajo. Następnie zabezpieczają go tzw. korkiem, czyli lepką substancją zmieszaną ze skrobią ziarna. Samice kapturnika zbożowca składają jaja na powierzchni ziarna, a wylęgające się larwy wgryzają się do jego środka, gdzie zachodzi ich dalszy rozwój. Pierwsze stadia larwalne $R$. dominica mogą żerować na pyle, który wytwarzają postacie dorosłe, a następnie wgryzają się do ziarna wykorzystując uszkodzenia dokonane przez osobniki dorosłe lub naturalne pęknięcia i uszkodzenia ziarniaków (Gołębiowska 1969;
Edde 2012). Różnice w sposobie zasiedlania ziarna mogą wpływać na intensywność rozwoju koegzystujących ze sobą populacji tych szkodników lub ewentualne wymarcie osobników jednej z nich. Poznanie charakterystyki rozwoju populacji obu gatunków szkodników w czasie ich wspólnego rozwoju, a także prześledzenie tych zmiennych w momencie, gdy jeden ze szkodników ma dominację liczebną w momencie zasiedlania ziarna lub wcześniej je zasiedla, może być pomocne w prognozowaniu i ocenie szkód przez nie powodowanych.

Celem badań było określenie dynamiki rozwoju $S$. granarius i $R$. dominica $\mathrm{w}$ czasie ich wspólnego rozwoju na ziarnie jęczmienia. Badano parametry populacji szkodników w kombinacjach, gdy miały identyczne warunki do rozwoju lub jeden $\mathrm{z}$ nich miał przewagę: liczebnościową lub w czasie zasiedlenia.

\section{Materiały i metody / Materials and methods}

\section{Material}

Ocenie poddano wspólny rozwój kapturnika zbożowca oraz wołka zbożowego rozwijających się na ziarnie jęczmienia jarego odmiany Blask. Przed rozpoczęciem doświadczenia ziarno kondycjonowano przez 7 dni w takich samych warunkach, w jakich rozwijały się następnie badane szkodniki. Po tym czasie ziarno przesiewano przez sito o oczkach $1 \mathrm{~mm}$, celem odsiania pyłu. Następnie naważano $50 \mathrm{~g}$ próbki ziarna do plastikowych pojemników (średnica $9 \mathrm{~cm}$, wysokość $3 \mathrm{~cm}$ ) z otworem wentylacyjnym zabezpieczonym szyfonową siatką. Do tak przygotowanych pojemników wpuszczano badane szkodniki i umieszczano je w komorze klimatyzacyjnej Sanyo MLR-350H. Wewnątrz komory panowały stałe warunki termiczno-wilgotnościowe. Ze względu na różne wymagania termiczne badanych gatunków (S. granarius $-26^{\circ} \mathrm{C}, R$. dominica $-30^{\circ} \mathrm{C}$ ), wybrano temperaturę pośrednią $-28^{\circ} \mathrm{C}$. Wilgotność względna powietrza wynosiła $70 \%$. Chrząszcze obu gatunków pochodziły z hodowli masowej prowadzonej w Katedrze Entomologii, Fitopatologii i Diagnostyki Molekularnej Uniwersytetu Warmińsko-Mazurskiego w Olsztynie.

\section{Metody}

$\mathrm{Na}$ ziarno badanych kombinacji nanoszono dorosłe osobniki chrząszczy (1-2-dniowe, stosunek płci 1:1) (Nietupski i wsp. 2017). Ich rozwój przebiegał przez 3 tygodnie, a następnie je usuwano. Monitoring rozwoju szkodników prowadzono do 8 tygodnia, co 7 dni. Po zakończeniu doświadczenia ustalano liczebność pokolenia potomnego chrząszczy, masę pyłu oraz ubytek masy ziarna. Do pomiaru masy użyto wagi laboratoryjnej WPS $220 / \mathrm{C} / 2$. W przeprowadzonych badaniach oceniano rozwój szkodników ziarna stosując poniższe kombinacje. W omówieniu wyników i dyskusji zastosowano skróty kombinacji podane w opisie: 
- kombinacja kontrolna (K_Sg). Na ziarno jęczmienia nanoszono 10 osobników $S$. granarius,

- kombinacja kontrolna (K_Rd). Nanoszono 10 dorosłych osobników $R$. dominica,

- kombinacja K1. Nanoszono 10 imagines $R$. dominica (K1Rd) i 10 imagines $S$. granarius $(\mathrm{K} 1 \mathrm{Sg})$,

- kombinacja K2. Nanoszono 20 imagines S. granarius (K2Sg) i 10 imagines $R$. dominica (K2Rd),

- kombinacja K3. Nanoszono 10 imagines S. granarius (K3Sg) i 20 imagines $R$. dominica (K3Rd),

- kombinacja K4. Nanoszono 10 imagines S. granarius (K4Sg). Po 7 dniach do pojemników wpuszczano 10 imagines $R$. dominica (K4Rd),

- kombinacja K5. Na próbki ziarna nanoszono 10 imagines $R$. dominica (K5Rd). Po 7 dniach do pojemników wpuszczono 10 imagines $S$. granarius (K5Sg).

Każdą kombinację przeprowadzono w 10 powtórzeniach.

\section{Analiza statystyczna}

Ocenę charakteru rozkładu danych, dotyczących liczebności osobników potomnych, ubytku masy ziarniaków, masy pyłu wytworzonego przez chrząszcze wykonano za pomocą testu W Shapiro-Wilka. Różnice między średnimi charakteryzującymi się rozkładem unimodalnym oceniano stosując uogólniony model liniowy GLM (Generalized Linear Model) uwzględniający typ rozkładu danych Poisson'a. Grupy średnich, badanych parametrów związanych z rozwojem szkodników w określonych kombinacjach, nieróżniących się statystycznie, oznaczono tym samym indeksem literowym: a, b, c ... (test Tukey'a HSD). W celu określenia zależności między badanymi parametrami rozwojowymi szkodników w różnych kombinacjach wyliczono współczynnik korelacji liniowej $r$ Pearsona. Obliczenia statystyczne i ich graficzną interpretację wykonano przy użyciu programu STATISTICA 13.1.

\section{Wyniki i dyskusja / Results and discussion}

Parametry związane z intensywnością rozwoju $S$. granarius i $R$. dominica na badanym ziarnie jęczmienia określano oceniając liczebność pokolenia potomnego szkodnika, masę wytworzonego pyłu oraz ubytek masy ziarniaków. Uzyskane średnie dla badanych kombinacji miały rozkład unimodalny, dlatego do oceny istotności różnic zastosowano uogólniony model liniowy (GLM). Wyniki tego testu wykazały, że różnice między średnimi badanych parametrów z poszczególnych kombinacji były istotne statystycznie (tab. 1). Największą liczebnością pokolenia potomnego charakteryzowały się kombinacje (oprócz K4), w których rozwijał się $R$. dominica. Gatunek ten był najliczniejszy (śr. 80,6 osobników) w kombinacji K3, w której jego populacja startowa była 2-krotnie liczniejsza od $S$. granarius (rys. 1). Istotnie mniej osobników potomnych $R$. dominica (132,3 osobników) stwierdzono w kombinacji K5Rd, gdzie szkodnik ten rozwijał się o 10 dni dłużej niż wołek zbożowy. Na kombinacji kontrolnej (K_Rd) rozwój zakończyło średnio 116,1 osobników $R$. dominica. W kombinacjach, w których rozwijały się identyczne populacje szkodników (K1Rd, śr. 85,6 osobników) lub na starcie, przewagę ilościową miał S. granarius (K2Rd, śr. 77,3 osobników), a liczebność pokolenia potomnego kapturnika zbożowca była podobna, zaszeregowana przez test HSD Tukey'a do tej samej grupy jednorodnej. Wołek zbożowy natomiast wytworzył najliczniejszą populację potomną w kombinacji kontrolnej (K_Sg, śr. 67,0 osobników) oraz gdy miał przewagę liczebnościową na starcie (K2Sg) (rys. 1). W kombinacji, w której S. granarius zaczynał rozwój wcześniej niż $R$. dominica (K4Sg) liczebność jego populacji kształtowała się na średnim poziomie 42,8 osobników. Liczebność populacji potomnej wołka zbożowego w kombinacjach: K1Sg (identyczne populacje startowe) i K3Sg (przewaga $R$. dominica na starcie) była podobna do populacji potomnej kapturnika, którego rozwój opóźniono o 7 dni (K4Rd). Wszystkie te wartości należały do jednej grupy jednorodnej. Najmniej liczną populację potomną, spośród wszystkich kombinacji, wytworzył wołek zbożowy, gdy zasiedlił ziarno jęczmienia o tydzień później niż kapturnik (K5Sg, śr. 18,1 osobników).

Jednym z parametrów opisujących intensywność rozwoju pierwotnych szkodników magazynowych jest masa pyłu powstającego w trakcie ich żerowania. Największą jego ilość (śr. 3,94 g) odnotowano w kombinacji, w której żerowało 10 osobników S. granarius i $20 \mathrm{R}$. dominica (K3) (rys. 2). Nieco niższe wartości masy pyłu (śr. 3,06 g) stwierdzono w kombinacji K5, gdzie osobniki S. granarius dołączyły do $R$. dominica po 7 dniach. Masa pyłu

Tabela 1. Wynik uogólnionego modelu liniowego (GLM) dla liczebności pokolenia potomnego Sitophilus granarius i Rhyzopertha dominica, masy wytworzonego pyłu oraz ubytku masy ziarniaków w badanych kombinacjach

Table 1. Results of the generalised linear model (GLM) for abundance of the progeny generation of Sitophilus granarius and Rhyzopertha dominica, mass of formed dust, and loss of the mass of kernels in the analysed variants

\begin{tabular}{l|c|c|c}
\cline { 2 - 4 } & Stopnie swobody df - Degrees of freedom & Statystyka Walda - Wald's statistic & $\mathrm{p}^{*}$ \\
\hline Osobniki potomne - Progeny of beetles & 11 & 3167,64 & 0 \\
Masa pyłu - Mass of dust & 11 & 56,64 & 0 \\
Ubytek masy ziarna - Loss of grain mass & 11 & 78,74 & 0 \\
\hline
\end{tabular}

\footnotetext{
*wartość prawdopodobieństwa testowego p - p-value
} 
wytworzonego przez żerujące chrząszcze obu gatunków w doświadczeniach K1, K2 i kontroli K Rd kształtowała się na podobnym poziomie (śr. 2,01-4,99 g), zaszeregowanym do tej samej grupy jednorodnej. Istotnie mniej pyłu (śr. 0,59 g) stwierdzono w kombinacji K4, gdzie osobniki $R$. dominica nanoszono po 7 dniach od momentu rozpoczęcia żerowania przez $S$. granarius. Najmniej pyłu odnotowano w kontroli, na której rozwijał się tylko wołek zbożowy (K_Sg, śr. 0,16 g) (rys. 2). Kolejnym parametrem związanym z intensywnością żerowania i rozwojem szkodników magazynowych jest ubytek masy ziarna. Jego wartości w poszczególnych kombinacjach były bardzo podobne do masy wytworzonego pyłu. Największe ubytki w masie ziarna odnotowano w kombinacji K3 (śr. 6,07 g), gdzie $R$. dominica żerował w przewadze liczebnej. Istotnie mniejsze ubytki masy stwierdzono w doświadczeniach K2 i K5 (śr. 4,36-4,73 g) oraz K1 (śr. 3,33 g). W kombinacji kontroInej, $R$. dominica żerując spowodował ubytek masy ziarna na średnim poziomie 2,36 g. Najmniejsze ubytki stwierdzono natomiast w doświadczeniu K4 (śr. 1,45 g) i w kontroli z wołkiem zbożowym K_Sg (śr. 1,45 g) (rys. 3).

Analiza dynamiki rozwoju $S$. granarius (wylęg chrząszczy potomnych) wskazuje, że gatunek ten rozwijał się najintensywniej w kombinacji kontrolnej (K_Sg) oraz kombina-

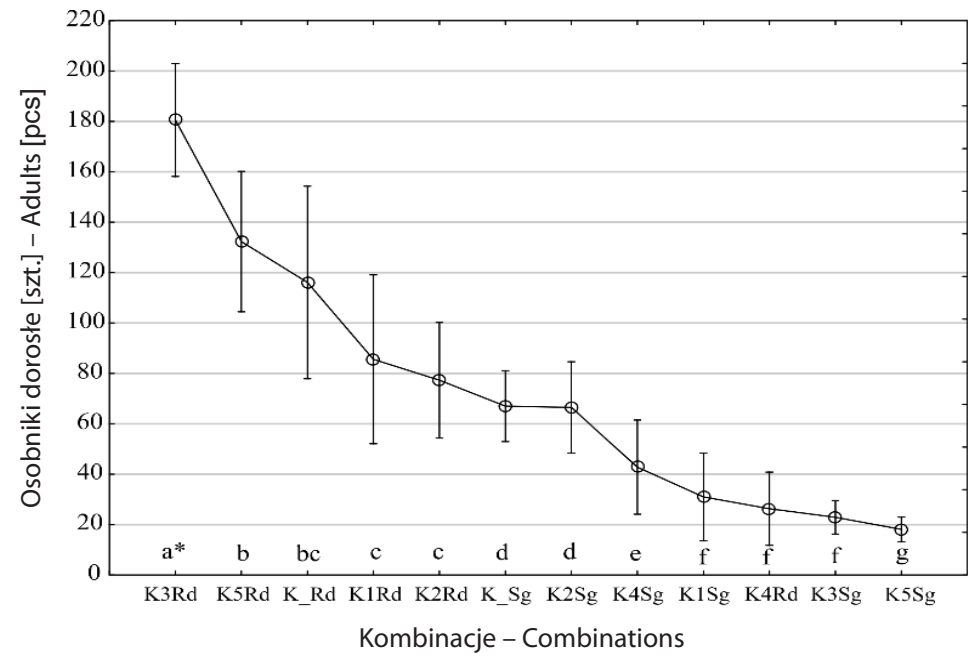

*średnie oznaczone tą samą literą nie różnią się istotnie (test HSD Tukey'a) ${ }^{*}$ means followed by the same letter do not differ (HSD Tukey's test)

Rys. 1. Liczebność pokolenia potomnego Sitophilus granarius i Rhyzopertha dominica w badanych kombinacjach

Fig. 1. Number of individuals in the progeny generations of Sitophilus granarius and Rhyzopertha dominica in the analysed variants

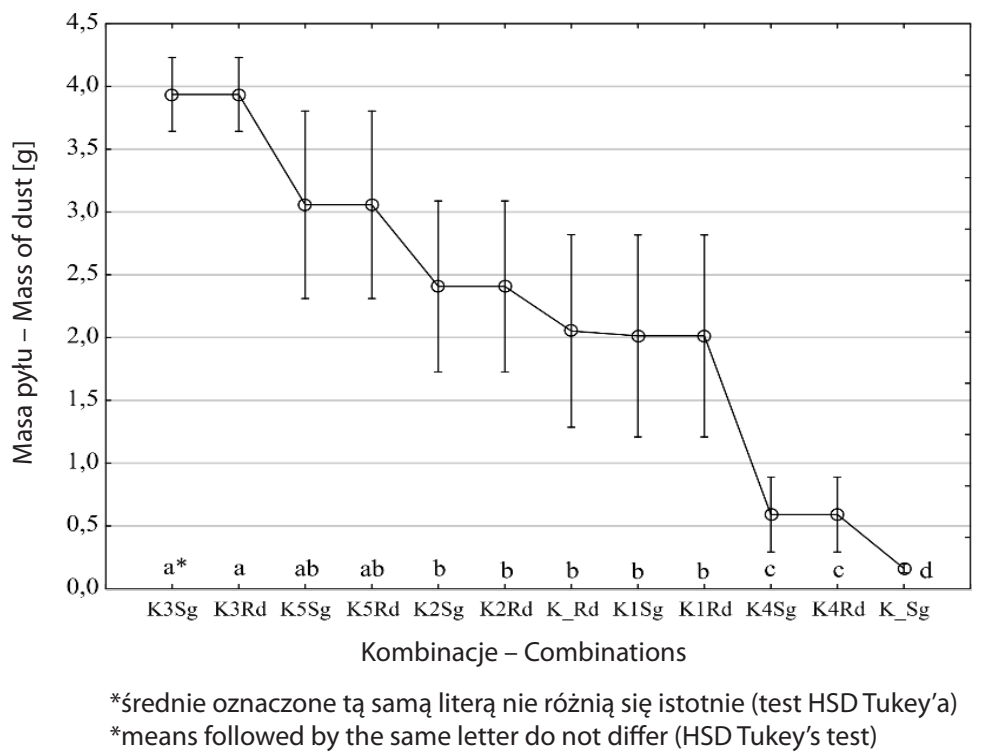

Rys. 2. Masa pyłu powstałego wskutek żerowania Sitophilus granarius i Rhyzopertha dominica w badanych kombinacjach Fig. 2. Mass of dust produced due to foraging by Sitophilus granarius and Rhyzopertha dominica in the analysed variants 
cji, w której miał przewagę liczebną na starcie doświadczenia (K2Sg) (rys. 4a). Stały, tygodniowy przyrost liczebności populacji potomnej $S$. granarius obserwowano również w pozostałych 4 kombinacjach. Najsłabszą dynamikę wylęgu pokolenia potomnego stwierdzono w doświadczeniu, w którym chrząszcz ten rozpoczął rozwój tydzień później niż $R$. dominica oraz gdy jego populacja startowa była mniej liczna niż wołka. W przypadku $R$. dominica zauważono również sukcesywny wzrost liczebności jego populacji potomnej w kolejnych tygodniach obserwacji (rys. 4b). Był on największy w kombinacji, w której kapturnik rozwijał się w przewadze liczebnej (K3Rd), a duży przyrost osobników pokolenia potomnego stwierdzono w 6-7 tygodniu rozwoju. W pozostałych kombinacjach przyrost ten był mniejszy
(K5Rd, K_Rd, K1Rd, K2Rd), najsłabszy w doświadczeniu, w którym kapturnik rozpoczął rozwój o tydzień później niż wołek zbożowy (K4Rd).

Pomiędzy badanymi parametrami, określającymi rozwój S. granarius i $R$. dominica, wyznaczono współczynnik korelacji liniowej $r$ Pearsona (tab. 2). Jego wartości jednoznacznie wskazują na dodatnią, liniową korelację między liczebnością pokolenia potomnego szkodników a wzrostem pojawiającego się pyłu oraz ubytku masy ziarna. W tabeli 3. zestawiono dodatkowo wartości współczynnika $r$ badanych parametrów rozwojowych w kombinacjach, gdzie chrząszcze rozwijały się wspólnie. Stwierdzono ujemną korelację dla liczebności populacji potomnych badanych szkodników. W kombinacji (K1), gdy chrząszcze miały ta-

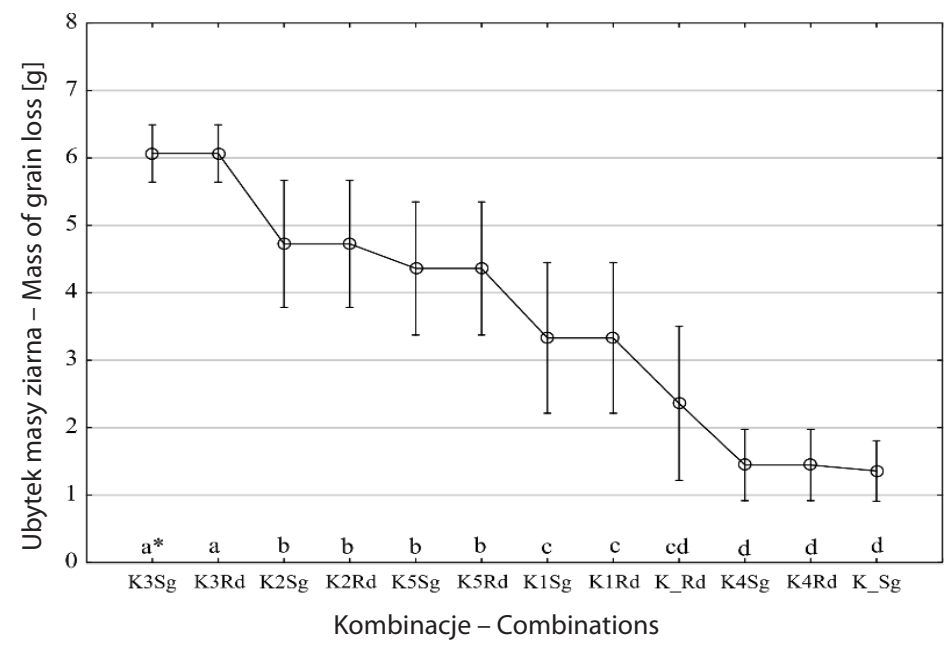

*'́rednie oznaczone tą samą literą nie różnią się istotnie (test HSD Tukey’a) ${ }^{*}$ means followed by the same letter do not differ (HSD Tukey's test)

Rys. 3. Ubytek masy ziarna powstały wskutek żerowania Sitophilus granarius i Rhyzopertha dominica w badanych kombinacjach Fig. 3. Loss of grain mass due to foraging by Sitophilus granarius and Rhyzopertha dominica in the analysed variants

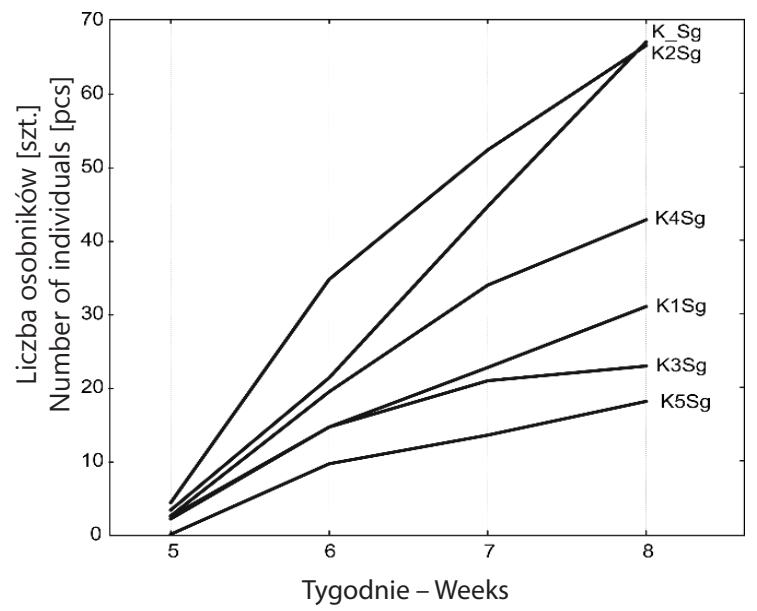

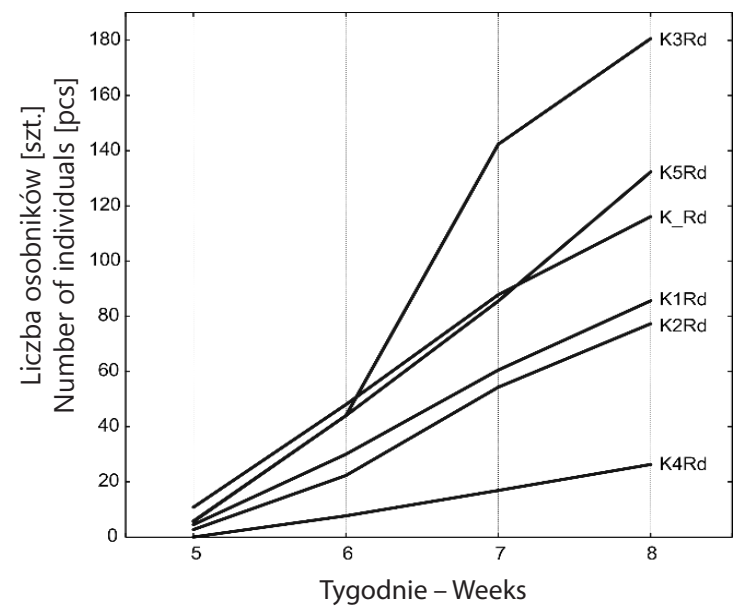

Rys. 4. Dynamika wylęgu postaci dorosłych Sitophilus granarius (a) i Rhyzopertha dominica (b) w badanych kominacjach

Fig. 4. Dynamics of the emergence of adult forms of Sitophilus granarius (a) and Rhyzopertha dominica (b) in the analysed variants 
kie same warunki rozwoju, $R$. dominica tworzył liczniejszą populację potomną przy dużych ilościach pyłu $(r=0,9)$. Odwrotną zależność $(r=-0,3)$ odnotowano dla $S$. granarius $\mathrm{w}$ kombinacjach, w których przewagę startową miał S. granarius (K2, K4), a pył pojawiający się wskutek żerowania wołka zbożowego, był zjadany przez młode larwy kapturnika. Przekładało się to na prawie liniową korelację tego parametru z liczebnością potomną tego chrząszcza (K2 i K4-r = 0,81) (tab. 3). Ta bardzo ścisła korelacja potwierdzona została w kolejnych doświadczeniach, w których przewagę startową miał $R$. dominica (K3, K5). Małe ilości pyłu, pojawiające się w czasie wspólnego rozwoju szkodników, wiązały się ze wzrostem liczebności populacji potomnej wołka zbożowego.

Wołek zbożowy i kapturnik zbożowiec to szkodniki pierwotne ziarna zbóż, które znajdują doskonałe warunki do rozwoju na pszenicy ozimej i jarej, pszenżycie ozimym, życie i jęczmieniu (Kordan i wsp. 2005; Nietupski i wsp. 2006, 2007, 2013; Edde 2012). Można je uznać za gatunki należące do najgroźniejszych szkodników przechowywanego ziarna zbóż w strefie klimatu umiarkowanego (Nawrot 1998; Edde 2012). W warunkach naturalnych występują w magazynach zbożowych żerując wspólnie z innymi gatunkami szkodników. Korzystają z tego gatunki wtórne, żerujące na ziarnie uszkodzonym, jednak obserwowany proces sukcesji gatunków (Hagstrum 1987) świadczyć może o istniejącej konkurencji między nimi (Athanassiou i wsp. 2014). W przeprowadzonym doświadczeniu w kombinacjach kontrolnych (K_Sg, K_Rd) badane gatunki chrząszczy rozwijały się dobrze, tworząc liczną populację potomną, wytwarzając duże ilości pyłu i powodując znaczne ubytki w masie ziarna (rys. 2, 3). Wysokie wartości tych parametrów są skorelowane z wysoką jakością pokarmu dla badanych gatunków chrząszczy (Niewiada i wsp. 2005; Park i wsp. 2008; Nawrot i wsp. 2010; Nietupski i wsp. 2013). W kombinacjach, w których szkodniki rozwijały się wspólnie, w większości przypadków bardziej intensywnym rozwojem charakteryzował się $R$. dominica. Jak podaje Kłyś
(2006) gatunek ten rozwija się bardzo dynamicznie na pokarmie rozdrobnionym (płatki owsiane), jednak największą przeżywalność larw autorka stwierdziła w kombinacji z ziarnem pszenicy. Wynika to prawdopodobnie z faktu osłony, jaką znajdują one żerując wewnątrz ziarniaka. Bardzo dobre warunki do rozwoju w przeprowadzonym doświadczeniu, jakie miał $R$. dominica żerując wspólnie z S. granarius, wynikać mogą m.in. z faktu dużej ilości pyłu oraz łatwiejszego dostępu do ziarna, którego okrywa uszkadzana była przez dorosłe osobniki obu gatunków. Potwierdzają to wyniki badań przeprowadzonych przez Kavallieratos i wsp. (2012), które dowodzą, że larwy $R$. dominica wybierają do rozwoju ziarno ryżu z uszkodzoną okrywą, pomijając ziarno nieuszkodzone. Kapturnik zbożowiec odnosi więc ewidentną korzyść z faktu wspólnego żerowania z wołkiem zbożowym. W kombinacjach, w których miał przewagę startową nad S. granarius (K3, K5), dominował pod względem liczebności pokolenia potomnego (rys. 1). Co więcej, parametr ten był również wyższy w kombinacji, w której wołek zbożowy miał przewagę liczebną na początku doświadczenia (K2). Prawdopodobnie większa liczba osobników S. granarius pozostawiała duże ilości pyłu i uszkodzonych ziarniaków, co wpływało korzystnie na rozwój larw $R$. dominica. Świadczyć o tym może prawie liniowa zależność $(r=0,81)$ w tej kombinacji między masą pyłu a liczebnością pokolenia potomnego kapturnika zbożowca (tab. 3).

W przypadku wołka zbożowego zaznacza się tendencja jego dynamiczniejszego rozwoju (rys. 4a) w kombinacjach, gdzie rozwija się sam (kontrola K_Sg) lub ma na starcie przewagę liczebną (K2Sg) i czasową (K4Sg). W pozostałych kombinacjach szybciej rozwija się $R$. dominica. Prawdopodobnie wynika to z faktu, że dorosłe $S$. granarius zasiedlając ziarno przez kilka dni intensywnie żerują, a dopiero później samice rozpoczynają składanie jaj. W przypadku $R$. dominica obserwowano, oprócz intensywnego żerowania w pierwszych dniach od zasiedlenia, również intensywne składanie jaj przez samice (Gołębiowska 1969). Wyliczone wartości współczynnika $r$ ujawniają jednoznaczną, ujemną

Tabela 2. Wartości współczynnika korelacji liniowej $r$ Pearsona między badanymi parametrami rozwojowymi populacji Sitophilus granarius i Rhyzopertha dominica

Table 2. Values of the Perason's $r$ linear correlation coefficient between the analysed development parameters of the populations of Sitophilus granarius and Rhyzopertha dominica

\begin{tabular}{|c|c|c|c|c|}
\hline & Imagines - Adults & & Masa pyłu - Mass of dust & \\
\hline & $r$ & $\mathrm{p}^{*}$ & $r$ & $\mathrm{p}^{*}$ \\
\hline \multicolumn{5}{|c|}{ Sitophilus granarius } \\
\hline Masa pyłu - Mass of dust & 0,91 & 0 & - & - \\
\hline Ubytek masy - Loss of weight & 0,95 & 0 & 0,97 & 0 \\
\hline \multicolumn{5}{|c|}{ Rhyzopertha dominica } \\
\hline Masa pyłu - Mass of dust & 0,98 & 0 & - & - \\
\hline Ubytek masy - Loss of weight & 0,98 & 0 & 1 & 0 \\
\hline
\end{tabular}

*wartość prawdopodobieństwa testowego p - p-value 
Tabela 3. Wartości współczynnika korelacji liniowej $r$ Pearsona między badanymi parametrami rozwojowymi populacji Sitophilus granarius i Rhyzopertha dominica (wspólny rozwój)

Table 3. Values of the Perason's $r$ linear correlation coefficient between the analysed development parameters of the populations of Sitophilus granarius and Rhyzopertha dominica (co-development)

\begin{tabular}{|c|c|c|c|c|}
\hline \multirow{2}{*}{$\begin{array}{l}\text { Wyszczególnienie } \\
\text { Specification }\end{array}$} & \multicolumn{2}{|c|}{$\begin{array}{l}\text { Dorosłe Sitophilus granarius }(\mathrm{Sg}) \\
\text { Adults fo Sitophilus granarius }(\mathrm{Sg})\end{array}$} & \multicolumn{2}{|c|}{$\begin{array}{l}\text { Dorosłe Rhyzopertha dominica (Rd) } \\
\text { Adults of Rhyzopertha dominica (Rd) }\end{array}$} \\
\hline & $r$ & $\mathrm{p}^{*}$ & $r$ & $\mathrm{p}^{*}$ \\
\hline \multicolumn{5}{|c|}{$\mathrm{Sg}=\mathrm{Rd}$} \\
\hline Imagines - Adults & $-0,56$ & 0,09 & - & - \\
\hline Masa pyłu-Mass of dust & $-0,30$ & 0,39 & 0,9 & 0 \\
\hline Ubytek masy - Loss of weight & 0,17 & 0,63 & 0,64 & 0,04 \\
\hline \multicolumn{5}{|c|}{$\mathrm{Sg}>\mathrm{Rd}$ (osobniki - individuals) $\mathrm{K} 2$} \\
\hline Imagines - Adults & $-0,64$ & 0,05 & - & - \\
\hline Masa pyłu - Mass of dust & 0,51 & 0,13 & 0,81 & 0 \\
\hline Ubytek masy - Loss of weight & $-0,01$ & 0,97 & 0,53 & 0,11 \\
\hline \multicolumn{5}{|c|}{$\mathrm{Sg}>\mathrm{Rd}$ (czas zasiedlenia - time of settling) K4 } \\
\hline Imagines - Adults & $-0,40$ & 0,25 & - & - \\
\hline Masa pyłu-Mass of dust & $-0,42$ & 0,22 & 0,81 & 0 \\
\hline Ubytek masy - Loss of weight & 0,49 & 0,15 & 0,29 & 0,41 \\
\hline \multicolumn{5}{|c|}{$\mathrm{Sg}<\mathrm{Rd}$ (osobniki - individuals) K3 } \\
\hline Imagines - Adults & $-0,26$ & 0,48 & - & - \\
\hline Masa pyłu-Mass of dust & $-0,64$ & 0,05 & 0,34 & 0,34 \\
\hline Ubytek masy - Loss of weight & 0,02 & 0,92 & 0,2 & 0,57 \\
\hline \multicolumn{5}{|c|}{$\mathrm{Sg}<\mathrm{Rd}$ (czas zasiedlenia - time of settling) K5 } \\
\hline Imagines - Adults & $-0,42$ & 0,23 & - & - \\
\hline Masa pyłu-Mass of dust & $-0,45$ & 0,19 & 0,91 & 0 \\
\hline Ubytek masy - Loss of weight & $-0,24$ & 0,5 & 0,89 & 0 \\
\hline
\end{tabular}

*wartość prawdopodobieństwa testowego p - p-value

korelację między liczebnościami populacji potomnych badanych szkodników (tab. 3). W rozwijających się wspólnie populacjach, wzrost liczebności jednego z gatunków pociąga za sobą spadek liczebności drugiego.

Uzyskane wyniki wskazują na kapturnika zbożowego jako gatunek, który wygrywa bezpośrednią rywalizację z wołkiem zbożowym. Na jego korzyść przemawia również zdolność do migracji między magazynami w okresie letnim (Klejdysz i Nawrot 2010) oraz relatywnie niskie temperatury minimalne rozwoju chrząszczy (Gołębiowska 1962; Longstaff 1999). Nie bez znaczenia jest również fakt, że kapturnik zbożowiec (larwy i imagines) w ciągu życia zjada średnio $154 \mathrm{mg}$ ziarna pszenicy, podczas gdy S. granarius $86 \mathrm{mg}$ (Hagstrum i Subramanyam 2006). Wszystkie te cechy wskazują, że gatunek ten może stać się wkrótce groźniejszym szkodnikiem pierwotnym ziarna zbóż niż wołek zbożowy w strefie klimatu umiarkowanego.

\section{Wnioski / Conclusions}

1. W przypadku samodzielnego rozwoju $S$. granarius i $R$. dominica stwierdzono liniową zależność między wzrostem liczebności populacji potomnej szkodnika a masą pyłu i ubytkiem masy ziarniaków.

2. Kapturnik zbożowiec jest gatunkiem o bardziej dynamicznym rozwoju niż wołek zbożowy. Mniejszą liczebność populacji tego szkodnika stwierdzono tylko w przypadku wariantu doświadczenia, w którym jego rozwój rozpoczął o tydzień później niż wołka zbożowego.

3. Wspólny rozwój szkodników stwarza lepsze warunki do rozwoju kapturnikowi zbożowemu, prawdopodobnie dzięki obecności większej masy pyłu wykorzystywanego przez młode larwy $R$. dominica oraz łatwiejszemu dostępowi do uszkodzonych ziarniaków.

\section{Literatura / References}

Athanassiou C.G., Kavallieratos N.G., Throne J.E., Nakas C.T. 2014. Competition among species of stored-product psocids (Psocoptera) in stored grain. PLoS ONE 9 (8): e102867. DOI: 10.1371/journal.pone.0102867 
Aulicky R., Stejskal V., Kucerova Z., Trematerra P. 2016. Trapping of internal and external feeding stored grain beetle pests with two types of pitfall traps: a two-year field study. Plant Protection Science 52 (1): 45-53. DOI: 10.17221/30/2015-PPS

Edde P.A. 2012. A review of the biology and control of Rhyzopertha dominica (F.) the lesser grain borer. Journal of Stored Product Research 48: 1-18. DOI: 10.1016/j.jspr.2011.08.007

Gołębiowska Z. 1962. Przyczynek do badań nad ekologią kapturnika zbożowca - Rhizopertha dominica F. (Col., Bostrichidae). Polskie Pismo Entomologiczne 32 (1-2): 39-51.

Gołębiowska Z. 1969. The feeding and fecundity of Sitophilus granarius (L.), Sitophilus oryzae (L.), and Rhyzopertha dominica (F.) in wheat grain. Journal of Stored Products Research 5 (2): 143-155. DOI: 10.1016/0022-474X(69)90056-3

Hagstrum D.W. 1987. Seasonal variation of stored wheat environment and insect populations. Environmental Entomology 16 (1): $77-83$. DOI: $10.1093 /$ ee/16.1.77

Hagstrum D.W. 2000. Using five sampling methods to measure insect distribution and abundance in bins storing wheat. Journal of Stored Products Research 36: 253-262.

Hagstrum D.W., Subramanyam B. 2006. Fundamentals od Stored-Product Entomology. AACC International, St. Paul, Minnesota, USA, 322 ss. ISBN-13: 978-1-891127-50-2.

Jia F., Toews M.D., Campbell J.F., Ramaswamy S.B. 2008. Survival and reproduction of lesser grain borer, Rhyzopertha dominica (F.) (Coleoptera: Bostrichidae) on flora associated with native habitats in Kansas. Journal of Stored Products Research 44 (4): $366-372$. DOI: 10.1016/j.jspr.2008.06.001

Kavallieratos N.G., Athanassiou C.G., Arthur F.H., Throne J.E. 2012. Lesser grain borers, Rhyzopertha dominica, select rough rice kernels with cracked hulls for reproduction. Journal of Insect Science 12 (38): 1-7. DOI: 10.1673/031.012.3801

Klejdysz T., Nawrot J. 2010. First record of outdoor occurrence of stored-product coleopterans in arable landscape in Poland. [Pierwsze stwierdzenie chrząszczy magazynowych w wolnej przyrodzie w Polsce]. Journal of Plant Protection Research 50 (4): 551-553. DOI: $10.2478 / \mathrm{v} 10045-010-0091-4$

Kłyś M. 2006. Nutritional preferences of the lesser grain borer Rhizopertha dominica F. (Coleoptera, Bostrichidae) under conditions of free choice of food. [Preferencje pokarmowe kapturnika zbożowca Rhizopertha dominica f. (Coleoptera, Bostrichidae) w warunkach swobodnego wyboru pokarmu]. Journal of Plant Protection Research 46 (4): 359-367.

Kordan B., Ciepielewska D., Nietupski M. 2005. Wpływ wybranych odmian zbóż na rozwój kapturnika zbożowca (Rhizopertha dominica F.). [Effect of cereal cultivars on the development of lesser grain borer (Rhizopertha dominica F.)]. Progress in Plant Protection/ Postępy w Ochronie Roślin 45 (2): 794-796.

Longstaff B.C. 1999. An experimental and modelling study of the demographic performance of Rhyzopertha dominica (F.). I. development rate. Journal of Stored Products Research 35 (1): 89-98. DOI: 10.1016/S0022-474X(98)00014-9

Nawrot J. 1998. The susceptibility of grain various wheat varieties and cultivars to the post harvest infestation by granary weevil (Sitophilus granarius L.). Prace Naukowe Instytutu Ochrony Roślin 23 (2): 135-140.

Nawrot J., Gawlak M., Szafranek J., Szafranek B., Synak E., Warchalewski J.R., Piasecka-Kwiatkowska D., Błaszczak W., Jeliński T., Fornal J. 2010. The effect of wheat grain composition, cuticular lipids and kernel Surface microstructure on feeding, egg-laying, and the development of the granary weevil, Sitophilus granarius (L.). Journal of Stored Product Research 46 (2): 133-141. DOI: 10.1016/j. jspr.2010.02.001

Nietupski M., Bujak E., Kordan B. 2013. Rozwój kapturnika zbożowca (Rhyzopertha dominica F.) na ziarnie jęczmienia browarnego i pastewnego. [Development of the lesser grain borer (Rhyzopertha dominica F.) on malt barley and fodder barley grain]. Progress in Plant Protection 53 (1): 59-63. DOI: 10.14199/ppp-2013-117

Nietupski M., Ciepielewska D., Fornal Ł. 2006. Wpływ zróżnicowania chemicznego białek w ziarnie wybranych odmian pszenicy na rozwój szkodników magazynowych. [Effect of the chemical protein diversity of selected wheat grain cultivars on the development of storage pests]. Progress in Plant Protection/Postępy w Ochronie Roślin 46 (2): 420-423.

Nietupski M., Ciepielewska D., Kordan B. 2007. Ziarno mieszańcowych odmian żyta jako siedlisko rozwoju rozkruszka drobnego (Tyrophagus putrescentiae Schrank). [Grain of hybrid varieties of rye as environment for development of storage mite Tyrophagus putrescentiae Schrank]. Progress in Plant Protection/Postępy w Ochronie Roślin 47 (1): 336-339.

Nietupski M., Kwiatkowski J., Kosewska A. 2017. Physicochemical properties of achenes of different buckwheat genotypes affecting the development of grain weevil (Sitophilus granarius L.) and lesser grain borer (Rhyzopertha dominica F.). Zemdirbyste-Agriculture 104 (4): 311-320. DOI 10.13080/z-a.2017.104.040

Niewiada A., Nawrot J., Szafranek J., Szafranek B., Synak E., Jeleń H., Wąsowicz E. 2005. Some factors affecting egg-laying of the granary weevil (Sitophilus granarius L.). Journal of Stored Product Research 41 (5): 544-555. DOI: 10.1016/j.jspr.2004.11.001

Park S.H., Arthur F.H., Bean S.R., Schober T.J. 2008. Impact of differing population levels of Rhyzopertha dominica (F.) on milling and physicochemical properties of sorghum kernel and flour. Journal of Stored Product Research 44 (4): 322-327. DOI: 10.1016/j. jspr.2008.02.008

Stejskal V., Hubert J., Aulicky R., Kucerova Z. 2014. Overview of present and past and pest-associated risks in stored food and feed products: European perspective. Journal of Stored Products Research 64 (Part B): 122-132. DOI: 10.1016/j.jspr.2014.12.006

Stejskal V., Hubert1 J., Kučerová Z., Munzbergová Z., Lukáš J., Žd’árková E. 2003. The influence of the type of storage on pest infestation of stored grain in the Czech Republic. Plant Soil Environment 49 (2): 55-62. DOI: 10.17221/4090-PSE

Vela-Coiffier E.L., Fargo W.S., Bonjour E.L., Cuperus G.W., Warde W.D. 1997. Immigration of insects into on-farm stored wheat and relationships among trapping methods. Journal of Stored Products Research 33 (2): 157-166. DOI: 10.1016/S0022474X(96)00043-4 